\title{
Contaminated blood continues to boil
}

\section{Last week's complaint by 97 mostly French physicians draws attention yet again to the need for a wider inquiry} into the origins of the contaminated blood scandal.

THE French scientific community has been astonishingly laggard in reacting to the imprisonment of the two people sent to jail last year for their part in the scandalous use of blood contaminated with HIV for the treatment of French haemophiliacs. The letter now sent to President François Mitterrand (see page 312), which argues that the sentences being served by Dr Michel Garretta and Professor JeanPierre Allain are unjust (as are the convictions, without sentence, of two others), may bring some comfort to the two scientists now in prison, but they are unlikely to carry much weight with the president. For one thing, Mitterrand will be able to say that it would be improper for a politician to intervene in the judicial process. For another, he has no incentive to reopen an inquiry into the conduct of his own government in the summer of 1984 , when the National Transfusion Service continued to supply contaminated blood products "while stocks last", in Garretta's infamous phrase.

There is no doubt that the sentences handed down last summer, at the end of what was essentially a second trial of the case against the four defendants, are unjust in an important sense. What went wrong in France in the early summer of 1985 was that the government decided to wait until the autumn, when a French rather than a US blood test would become available, before instituting the routine screening of blood for transfusion and the manufacture of blood products. How and why the decision to delay was taken has not been fully explored, but there is no doubt that the result was to confirm the newly privatized transfusion service in its (or Garretta's) complacent policy of wringing the full economic value from its existing blood-bank, much of which was already contaminated with HIV. Three years ago, Mitterrand himself appeared to accept that responsibility might lie more widely than with the National Transfusion Service, but his declared intention to set up a parliamentary commission to investigate the role of the prime minister (M. Laurent Fabius) among others was discovered to be out of time.

Those now in jail, or serving suspended sentences, are therefore scapegoats in some sense or other, and will rightly be so regarded at least until the government's own role in the affair has been fully investigated. Although the transfusion service had ceased formally to be a part of the public service (legally, it had become a public foundation), it remained subject to government supervision. Moreover, the government committees concerned knew of the dangers of contaminated blood - one of the charges against Dr Jacques Roux, then a senior official at the Ministry of Public Health, is that he had been so informed in writing by his codefendant Allain. In many ways, the two contaminated blood trials thus have much in common with the infamous (but aborted) Matrix-Churchill case in Britain, when officials of a company were prosecuted for selling arms illegally to Iraq despite the British government's knowledge that they had been acting in accordance with a secretly changed policy. The pity, in France, is that the law has been allowed to run its full course.

The treatment of Allain is especially hard. He argued early and often that it would be dangerous to continue using contaminated blood. In the eyes of the courts, his guilt is to have known of the danger when the policy of the transfusion service remained unchanged. But what, in such circumstances, is a public official to do? To broadcast his disquiet to the public, or to attempt to work within the bureaucracy that employs him? By their judgement, the French courts have placed onerous responsibilities on all potential whistleblowers, but have offered them no protection. The French government will find that an awkward precedent.

None of this diminishes the difficulty in which the government now finds itself. Although the victims of the contaminated blood and their families have been compensated financially, mere money has evidently not assuaged their outrage. Moreover, there is no doubt that scientists in public positions who, by neglect or mistaken advice, are responsible for public catastrophes, should be as accountable for the consequences as are other kinds of professional people. The danger now is that the case of the contaminated blood will permanently sour relations between the profession and the public, from which both will suffer.

\section{The plutonium regime}

Something must be done to safeguard plutonium internationally and to prevent the threat of its misuse.

A MERE four kilograms of weapons-grade plutonium with a volume of less than 250 cubic centimetres is enough to make a nuclear weapon. That is an important part of the incentive for the study over the past two years (see page 307) by the US National Academy of Sciences, and published on 31 January (Management and Disposition of Excess Weapons Plutonium). Given that the theft of such small quantities of a metal is physically within the grasp of children, the 